\title{
Application of polyoxometalate/carbon nitride nanotubes nanocomposite for directly methanol oxidation
}

\section{Doğrudan metil alkol oksidasyonu için polioksometalat/karbon nitrit nanotüp nanokompozitinin uygulanması}

\author{
Mehmet Lütfi YOLA ${ }^{*}$ iD \\ 1Department of Biomedical Engineering, Faculty of Engineering and Natural Sciences, Iskenderun Technical University, Hatay, \\ Turkey. \\ mehmetyola@gmail.com \\ Received/Geliș Tarihi: 21.10.2018, Accepted/Kabul Tarihi: 20.11.2018 \\ doi: $10.5505 /$ pajes.2018.48865 \\ * Corresponding author/Yazıșllan Yazar \\ Research Article/Araștırma Makalesi
}

\begin{abstract}
Fuel cell in this study consumes methanol as fuel and they are very important for clean environment and effective energy conversion. Graphitic carbon nitride $\left(g-C_{3} N_{4}\right)$ is carbon allotrope among carbon based nanomaterials. It consists of $C-N$ bonds in $\pi$-based polymer Polyoxometalates (POMs) are redox-active materials and have crucial potential for direct methanol oxidation and energy storage. POMs attract important interest because they included in high-valent metals and anionic metal oxides. In present report, the nanocomposite of polyoxometalate $/ C_{3} N_{4}$ NTs was synthesized and applied for fuel cell. Firstly, the structure of prepared nanocomposite was investigated by transmission electron microscope (TEM), $x$-ray photo electron spectroscopy (XPS) and scanning electron microscope (SEM). After that, the voltammetric measurements were performed by using nanocomposite modified electrode. The electrochemical active areas of $P O M-C_{3} N_{4} N T s / G C E$ and $C_{3} N_{4} N T s / G C E$ are $0.511 \mathrm{~cm}^{2}$ and $0.169 \mathrm{~cm}^{2}$, respectively. The prepared nanocomposite demonstrated active catalytic effect towards methanol.
\end{abstract}

Keywords: Nanokompozit, Karbon nitrit nanotüp, Polioksometalat, Doğrudan yakıt hücresi

\section{Introduction}

Fuel cell, which occur through consuming of methanol-based fuels are $25 \%$ more than compared to other fuels. Some of the fuels used in energy cell becomes inert and harmless. However, most of them accumulated in different parts of environment like agriculture or water samples and poses serious environmental risks. In a fuel cell, it is possible to convert the energy of the fuel directly into the electrical energy. Their union is only carried out by ion and electron transfer between these compartments [1],[2].

The fuel cell converts the energy of fuel directly into electrical energy through the electrochemical reaction producing electricity with external fuel (anode side) and oxidizer (cathode side). They react in an electrolyte/electrode unit. Generally, when the reactants enter the cell, the reaction products leave from the cell. Fuel cells can work forever as long as the required fuel and oxidant flow is achieved. The methanol fuel cell is very important source for clean, effective and active energy. In addition, it is utilized as suitable power source. The methanol as fuel in fuel cell is liquid at room temperature. It has effective energy density and low cost. In the system of direct fuel cell, there are two electrode systems such as positive and a negative

\begin{abstract}
Öz
Bu çalışmada geliștirilen yakıt hücresinde yakıt olarak metil alkol kullanılır. Methanol yakıt hücreleri özellikle temiz çevre ve etkili enerji dönüşümü için çok önemlidir. Grafit karbon nitrit $\left(g-C_{3} N_{4}\right)$ karbon bazl nanomateryaller arasinda kararlı karbon allotropudur. $\Pi$ bazlı polimer sisteminde elektron lokalizasyonu olmayan $C-N$ bağlarından oluşur. Polioksometalatlar (POMs) redoks-aktif maddelerdir ve doğrudan metanol oksidasyonu ve enerji depolama için hayati bir potansiyele sahiptir. POM'lar, yüksek değerli metaller ve anyonik metal oksitler içerdikleri için ilgi görmektedir.Bu çalıșmada, Polioksometalat/karbon nitrit nanotüp ( $\left.C_{3} N_{4} N T s\right)$ sentezlenmiş ve yakıt hücresi için uygulanmıștır. Öncelikle, hazırlanan nanokompozitin yapısı geçirgen elektron mikroskopu (TEM), x-Ișınları fotoelektron spektroskopisi (XPS) ve taramall elektron mikroskopu (SEM) kullanılarak incelenmistir. Daha sonra bu nanokompozit modifiyeli elektrot kullanilarak elektrokimyasal ölçümler gerçekleştirilmiştir. POM- $C_{3} N_{4} N T S / G C E$ ve $\mathrm{C}_{3} \mathrm{~N}_{4} \mathrm{NTS} / \mathrm{GCE}$ elektrotları elektrokimyasal aktif yüzeyleri sirasıyla $0.511 \mathrm{~cm}^{2}$ ve $0.169 \mathrm{~cm}^{2}$ olarak bulunmuştur. Hazırlanan nankompozit metil alkole karșı aktif bir katalitik etki göstermiștir.
\end{abstract}

Anahtar kelimeler: Nanocomposite, Carbon nitride nanotubes, Polyoxometalates, Direct fuel cell

electrodes in contact with a film including in hydrogen or hydronium ion [3]-[5].

New materials that are formed by combining at least two different materials at the macro level are called composite materials. The purpose of the composite production is to add new features to make the materials giving the suitable properties to the usage areas. (Strength, lightness, flexibility, cost, etc.). g- $\mathrm{C}_{3} \mathrm{~N}_{4}$ is carbon allotrope among carbon based nanomaterials. g- $\mathrm{C}_{3} \mathrm{~N}_{4}$ has important energy applications such as fuel cell. In its structure, van der waals interactions are dominant. It is utilized for nanosensor and catalytic applications. Its tubular structure $\left(\mathrm{C}_{3} \mathrm{~N}_{4} \mathrm{NTs}\right)$ is able to improve the transfer of ion and diminish the transfer of mass owing to effective edges [6]-[9]. Polyoxometalates (POMs) are redoxactive materials and have crucial potential for direct methanol oxidation and energy storage. POMs attract important interest because they included in high-valent metals and anionic metal oxides [10]-[13].

The target of this study is built up of a novel fuel cell, which is able to determine methanol effectively from supporting electrolyte via POM- $\mathrm{C}_{3} \mathrm{~N}_{4}$ NTs/GCE. For this purpose, the nanocomposite modified electrodes were prepared and characterized. 


\section{Experimental procedure}

\subsection{Chemicals}

The used agents in present work are H3PW12040, melamine, methanol, acetonitrile, perchloric acid were obtained from Merck, Germany and Sigma-Aldrich.

\subsection{Synthesis of nanomaterials}

The utg- $\mathrm{C}_{3} \mathrm{~N}_{4}$ and $\mathrm{C}_{3} \mathrm{~N}_{4}$ NTs were obtained according to work [14]. For nanocomposite preparation of $\mathrm{H}_{3} \mathrm{PW}_{12} \mathrm{O}_{40} / \mathrm{C}_{3} \mathrm{~N}_{4} \mathrm{NTs}$; $0.20 \mathrm{~g}$ of $\mathrm{POM}$ was dissolved in grade acetonitrile. This solution added into $0.50 \mathrm{~g}$ of utg- $\mathrm{C}_{3} \mathrm{~N}_{4}$. After $2 \mathrm{~h}$, the hydrothermal treatment at $2000{ }^{\circ} \mathrm{C}$ applied to the solution. After drying at $50{ }^{\circ} \mathrm{C}, \mathrm{POM}-\mathrm{C}_{3} \mathrm{~N}_{4}$ NTs was evaluated [15].

\subsection{Procedure for the electrode preparation}

Glassy carbon electrode (GCE) was prepared according to the reports [16],[17]. After that, the POM and POM-C ${ }_{3} \mathrm{~N}_{4}$ NTs catalyts were prepared into $2.0 \mathrm{~mL}$ of ethanol. After that, the solvent was removed by IR.

\section{$2.4 \quad$ Electrochemical measurements}

In present study, the modified electrodes were utilized as working catalysts in fuel cell system. The fuel (methanol) was prepared in $0.1 \mathrm{~mol} \mathrm{~L}^{-1}$ perchloric acid. After the potential application to working electrode, the electrochemical data were obtained relating to methanol oxidation.

\section{Results and discussions}

\subsection{Characterization of nanomaterials}

Figure $1 \mathrm{~A}$ shows the aggregated structure of $\mathrm{g}-\mathrm{C}_{3} \mathrm{~N}_{4}$. Ultra-thin g- $\mathrm{C}_{3} \mathrm{~N}_{4}$ was generated under ultrasonication (Figure 1B). Tubular $\mathrm{C}_{3} \mathrm{~N}_{4}$ NTs nanostructure was formed by hydrothermal treatment at $200{ }^{\circ} \mathrm{C}$. Figure $1 \mathrm{C}$ verifies the tubular structure of $\mathrm{C}_{3} \mathrm{~N}_{4}$ NTs. Figure 1D shows the TEM image of the nanoscale of the POM-C $\mathrm{C}_{3} \mathrm{~N}_{4}$ NTs. POM clouds on surfaces of $\mathrm{C}_{3} \mathrm{~N}_{4}$ NTs were obtained. Therefore, it can be said that the interface interaction between POM and $\mathrm{C}_{3} \mathrm{~N}_{4}$ NTs results in POM-C $\mathrm{C}_{3} \mathrm{~N}_{4}$ NTs formation.

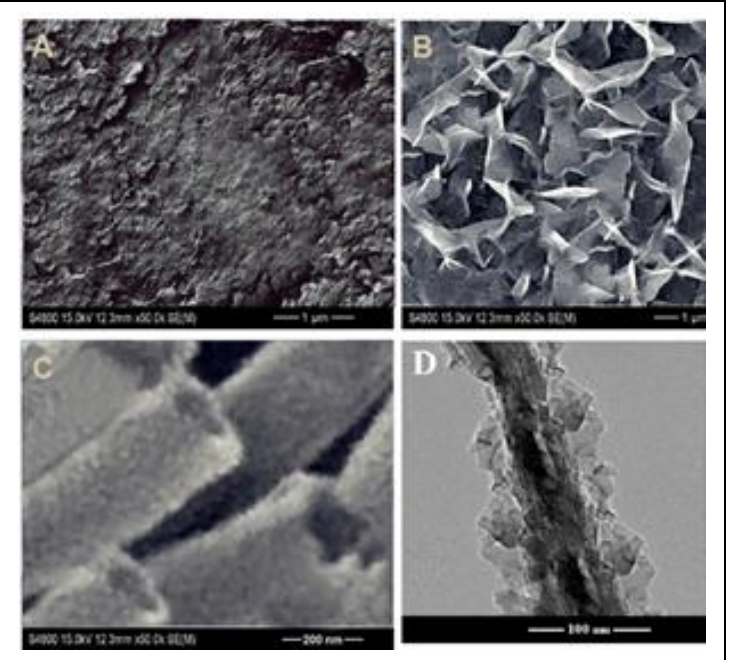

Figure 1: SEM images of prepared nanomaterials in present study.

XPS analysis confirms POM- $\mathrm{C}_{3} \mathrm{~N}_{4}$ NTs presence (Figure 2). The peaks relating to $\mathrm{C} 1 \mathrm{~s}, \mathrm{~N} 1 \mathrm{~s}, \mathrm{P} 2 \mathrm{~s}, \mathrm{~W} 4 \mathrm{f}$ and $01 \mathrm{~s}$ confirm the interfacial interaction between POM and $\mathrm{C}_{3} \mathrm{~N}_{4}$ NTs materials.

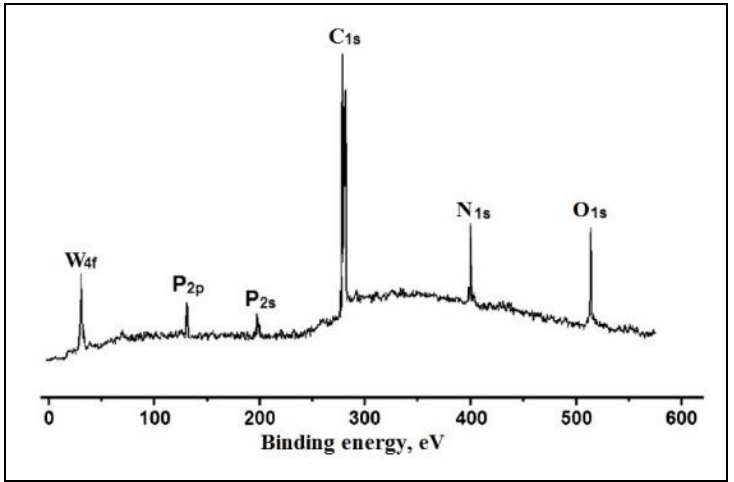

Figure 2: XPS image of POM-C $3 \mathrm{~N}_{4}$ NTs nanocomposite.

\subsection{Electrochemical performances of modified electrodes}

Firstly, the electroactive areas of $\mathrm{C}_{3} \mathrm{~N}_{4} \mathrm{NTs} / \mathrm{GCE}$ and POM-C $3 \mathrm{~N}_{4}$ NTs/GCE was calculated by cyclic voltammetry by "ip=2.69 $\times 10^{5} \mathrm{~A} \mathrm{n}^{3 / 2} \mathrm{D}^{1 / 2} \mathrm{C} \mathrm{v}^{1 / 2}$ " where ip is the signal, $\mathrm{C}$ is the concentration of $\left[\mathrm{Fe}(\mathrm{CN})_{6}\right]^{3-}, \mathrm{v}$ is the scan rate and $\mathrm{A}$ is the surface area $\left(\mathrm{cm}^{2}\right)$. The electrochemical active areas of POM- $\mathrm{C}_{3} \mathrm{~N}_{4}$ NTs/GCE and $\mathrm{C}_{3} \mathrm{~N}_{4}$ NTs/GCE are 0.511 and 0.169 $\mathrm{cm}^{2}$, respectively. The electrocatalytic activities towards $0.5 \mathrm{M}$ methanol in perchloric acid were explained by using prepared electrodes in this work. The current peaks were evaluated during forward and reverse scans (Table 1). The If of POM- $\mathrm{C}_{3} \mathrm{~N}_{4}$ NTs/GCE was 3.67 times higher than that of $\mathrm{C}_{3} \mathrm{~N}_{4}$ NTs/GCE, respectively (Table 1).

Table 1: Comparison of modified electrodes against methanol oxidation.

\begin{tabular}{cccccc}
\hline Electrode & $\begin{array}{c}\text { If } \\
\left(\mathrm{A} \mathrm{cm}^{-2}\right)\end{array}$ & $\begin{array}{c}\mathrm{E} \\
(\mathrm{V})\end{array}$ & $\begin{array}{c}\mathrm{Ib} \\
\left(\mathrm{A} \mathrm{cm}^{-2}\right)\end{array}$ & $\begin{array}{c}\mathrm{E} \\
(\mathrm{V})\end{array}$ & If/Ib \\
\hline $\begin{array}{c}\mathrm{POM}-\mathrm{C}_{3} \mathrm{~N}_{4} \\
\mathrm{NTs} / \mathrm{GCE}\end{array}$ & $8.11 \pm 0.08$ & $0.87 \pm 0.01$ & $5.39 \pm 0.02$ & $0.68 \pm 0.03$ & 1.50 \\
$\mathrm{C}_{3} \mathrm{~N}_{4}$ & $2.21 \pm 0.03$ & $0.91 \pm 0.02$ & $1.31 \pm 0.01$ & $0.76 \pm 0.02$ & 1.69 \\
$\mathrm{NTs} / \mathrm{GCE}$ & & & & & \\
\hline
\end{tabular}

The measurements of constant-current discharge were performed at $75 \mathrm{~mA} \mathrm{~m}^{-2}$ by prepared electrodes in this work. Figure 3 indicates different profiles of discharge. The discharge potentials of POM- $\mathrm{C}_{3} \mathrm{~N}_{4}$ NTs/GCE and $\mathrm{C}_{3} \mathrm{~N}_{4}$ NTs/GCE are -0.47 and $-0.35 \mathrm{~V}$, respectively. Because the discharge potential of $\mathrm{POM}-\mathrm{C}_{3} \mathrm{~N}_{4} \mathrm{NTs} / \mathrm{GCE}$ is the more negative than that of POM- $\mathrm{C}_{3} \mathrm{~N}_{4}$ NTs, its operational voltage can be higher. These results indicate that the nanocomposite performs a higher power density and faster reaction rate

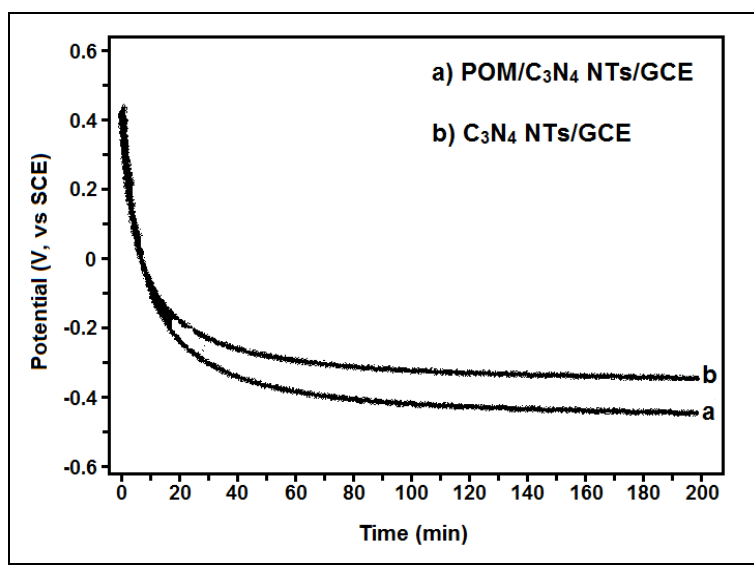

Figure 3: Potential-time curve of electrodes in $0.1 \mathrm{M}$ phosphate buffer. 


\section{Conclusions}

In present work, the novel nanocomposite including polyoxometalate and carbon nitride nanotubes was prepared for methanol oxidation. After various characterization studies, the electrochemical performances tests towards methanol were carried out. According to the test, the nanocomposite (POM- $\mathrm{C}_{3} \mathrm{~N}_{4}$ NTs) performs a higher power density and faster reaction rate. Therefore, we can indicate that more clean energy and environments can be obtained by using the nanocomposite modified electrode. In addition, the electrochemical measurements show that the more effective catalyst is presented for fuel cell applications in the literature.

\section{References}

[1] Yola ML, Eren T, Atar N, Saral H, Ermiș İ. "Direct-methanol fuel cell based on functionalized graphene oxide with mono-metallic and bi-metallic nanoparticles: Electrochemical performances of nanomaterials for methanol oxidation". Electroanalysis, 28(3), 570-579, 2016.

[2] Akyıldırım 0, Kotan G, Yola ML, Eren T, Atar N. "Fabrication of bimetallic Pt/Pd nanoparticles on 2-thiolbenzimidazole functionalized reduced graphene oxide for methanol oxidation". Ionics, 22(4), 593-600, 2016.

[3] Akyıldırım O, Yüksek H, Saral H, Ermiș İ, Eren T, Yola ML. "Platinum Nanoparticles supported on nitrogen and sulfur-doped reduced graphene oxide nanomaterial as highly active electrocatalysts for methanol oxidation". Journal of Materials Science: Materials in Electronics, 27(8), 8559-8566, 2016.

[4] Medetalibeyoğlu H, Manap S, Yokuş ÖA, Beytur M, Kardaş F, Akyıldırım 0, Özkan V, Yüksek H, Yola ML, Atar N. "Fabrication of Pt/Pd nanoparticles/polyoxometalate/ionic liquid nanohybrid for electrocatalytic oxidation of methanol". Journal of The Electrochemical Society, 165(5), F338-F341, 2018.

[5] Kwork YH, Wang YF, Tsang ACH, Leung DYC. "Graphenecarbon nanotube composite aerogel with Ru@Pt nanoparticle as a porous electrode for direct methanol microfluidic fuel cell". Applied Energy, 217, 258-265, 2018.

[6] Dong G, Zhang Y, Pan Q, Qiu J. "A fantastic graphitic carbon nitride (g-C3N4) material: Electronic structure, photocatalytic and photoelectronic properties". Journal of Photochemistry and Photobiology C: Photochemistry Reviews, 20, 33-50, 2014.

[7] Mazloum-Ardakani M, Aghaei R, Abdollahi-Alibeik M, Moaddeli A. "Fabrication of modified glassy carbon electrode using graphene quantum dot, gold nanoparticles and 4-(((4-mercaptophenyl)imino)methyl) benzene-1,2diol by self-assembly method and investigation of their electrocatalytic activities". Journal of Electroanalytical Chemistry, 738, 113-122, 2015.
[8] Niu P, Qiao M, Li Y, Huang L, Zhai T. "Distinctive defects engineering in graphitic carbon nitride for greatly extended visible light photocatalytic hydrogen evolution". Nano Energy, 44, 73-81, 2018.

[9] Wei Z, Liu M, Zhang Z, Yao W, Tan H, Zhu Y. "Efficient visible-light-driven selective oxygen reduction to hydrogen peroxide by oxygen-enriched graphitic carbon nitride polymers". Energy \& Environmental Science, 11(9), 2581-2589, 2018.

[10] Atar N, Yola ML, Eren T. "Sensitive determination of citrinin based on molecular imprinted electrochemical sensor". Applied Surface Science, 362, 315-322, 2016.

[11] Eren T, Atar N, Yola ML. "Facile and green fabrication of silver nanoparticles on a polyoxometalate for $\mathrm{Li}$ ion battery". Ionics, 21(8), 2193-2199, 2015.

[12] Yola ML, Gupta VK, Atar N. "New molecular imprinted voltammetric sensor for determination of ochratoxin A". Materials Science and Engineering C, 61, 368-375, 2016.

[13] Ertan B, Eren T, Ermiş İ, Saral H, Atar N, Yola ML. "Sensitive analysis of simazine based on platinium nanoparticles on polyoxometalate/multi-walled carbon nanotubes". Journal of Colloid and Interface Science, 470, 14-21, 2016.

[14] Yola ML, Eren T, Atar N. "A Molecular Imprinted Voltammetric Sensor Based on Carbon Nitride Nanotubes: Application to Determination of Melamine". Journal of The Electrochemical Society, 163(13), 588-593, 2016.

[15] Li K, Yan L, Zeng Z, Luo S, Luo X, Liu X, Guo H, Guo Y. "Fabrication of H3PW12040-doped carbon nitride nanotubes by one-step hydrothermal treatment strategy and their efficient visible-light photocatalytic activity toward representative aqueous persistent organic pollutants degradation". Applied Catalysis B: Environmental, 156-157, 141-152, 2014.

[16] Yola ML, Eren T, Atar N. "A sensitive molecular imprinted electrochemical sensor based on gold nanoparticles decorated graphene oxide: Application to selective determination of tyrosine in milk". Sensors and Actuators B: Chemical, 210, 149-157, 2015.

[17] Yola ML, Atar N, Qureshi MS, Üstündağ Z, Solak AO. "Electrochemically grafted etodolac film on glassy carbon for $\mathrm{Pb}(\mathrm{II})$ determination". Sensors and Actuators B: Chemical, 171-172, 1207-1215, 2012. 